\title{
Nutrient removal effectivity of seaweeds as biofilter and water pollution control in hybrid grouper aquaculture wastewater at low salinity
}

Ratih Ida Adharini ( $\square$ ratih.adharini@ugm.ac.id)

Universitas Gadjah Mada https://orcid.org/0000-0001-6966-3097

Murwantoko Murwantoko

Department of Fisheries Faculty of Agriculture Universitas Gadjah Mada

Namastra Probosunu

Department of Fisheries Faculty of Agriculture Universitas Gadjah Mada

Riza Yuliratno Setiawan

Department of Fisheries Faculty of Agriculture Universitas Gadjah Mada

Tony Budi Satriyo

Department of Fisheries Faculty of Agriculture Universitas Gadjah Mada

\section{Research}

Keywords:

Posted Date: February 2nd, 2021

DOI: https://doi.org/10.21203/rs.3.rs-149402/v3

License: (9) This work is licensed under a Creative Commons Attribution 4.0 International License. Read Full License 


\section{Abstract}

This research aims to determine the performance and nutrient removal effectivity of seaweeds species, namely Ulva fasciata., Sargassum illicifolium, Gelidium sp., and Dictyota sp. as a biofilter in hybrid grouper aquaculture wastewater at low salinity (14-17 ppt). This study used a Completely Randomized Design with 3 replications. The statistical analysis was carried out by Analysis of Variance continued with the Least Significance Difference test, and the Kruskal-Walis test with the Mann-Whitney analysis, and T-test with a confidence level of $95 \%$. The concentrations of ammonia, nitrate, phosphate, and water quality parameters were observed every 4 days. The seaweeds removal of $\mathrm{N}$ and $\mathrm{P}$ in water, and Specific Growth Rate were also observed. The results showed that U. fasciata was able to remove or reduce ammonia by $75.95 \%$ and nitrate by $79.53 \%$, which were the highest compared to other treatments, while Dictyota sp. was able to reduce the highest phosphate by $87.5 \%$ for 20 days. The highest SGR was achieved by $\mathrm{U}$. fasciata at $1.91 \%$ day -1 . The highest $\mathrm{N}$ content uptake by seaweeds was $104.4 \%$, and the total P of $182.3 \%$ occurred in U. fasciata . Overall, U. fasciata has the highest performance and effectiveness as a biofilter that is able to reduce nutrient waste in low-salinity from grouper aquaculture, for re-circulation or before being discharged into the environment to reduce eutrophication and Harmful Algal Blooms (HABs) in open water system. The highest growth rate of $U$. fasciata can be used as food with highly nutritional and economical value. Keywords : seaweeds, biofilter, hybrid grouper, wastewater, nutrient removal 